\title{
Institutional Support of the Renewable Energy Industry in Ukraine
}

\author{
Riazanova Nataliia ${ }^{1}$ \\ I State Establishment "Luhansk Taras Shevchenko National University" \\ *Corresponding author E-mail:natalirozez1975@gmail.com
}

\begin{abstract}
The article considers the institutional aspect of the renewable power industry development in Ukraine as a complex of formal and informal institutions, certain rules that actively influence the development and implementation of technologies. The development of the renewable energy industry through institutional transformations should be at the highest hierarchical level. The factors hindering the development of renewable energy sources (RES) are highlighted and systematized. In order to eliminate these factors, significant institutional changes that can not be carried out outside targeted state policies are needed, including financial support for the industry, the elimination of regulatory barriers, and the formation of demand for equipment by the strengthening of environmental norms and other tools for stimulating the development of renewable energy power industry and coordination of energy market participants. Key segments that influence the development of RES are formulated. Certain institutional transformations are needed for qualitative development of renewable energy power industry in Ukraine. Necessary institutional changes in energy supply, and now the state needs to systematize and harmonize the RES-policy. Institutional transformations are reduced to the problems of the development of renewable energy power industry in Ukraine, the ways of their solution are determined. The actions of economic entities in the economic space with the distribution (regulation) of each of them for the stable functioning of the system, which are the basis of the institutional relationship of rene wable energy sources in Ukraine for the purpose of energy saving, are presented.
\end{abstract}

Keywords: institutional support, institutional factors, renewable energy, renewable energy sources.

\section{Introduction}

The share of renewable energy sources (RES) has been growing steadily in the world's fuel and energy balance over recent years. Even in 2008-2009 the number of new RES kept growing, despite the decline in hydrocarbon prices. And already in 2010, the performance of newly introduced capacities of RES exceeded the indicators of hydrocarbon energy. The development of wind and solar energy in percentages and now exceeds the indicators of traditional coal and gas industries. The global community supports the idea of eliminating dependence on carbohydrates.

The technical potential of RES in Ukraine exceeds the level of energy consumption. Despite the fact that Ukraine is provided enough with energy resources (but need to be developed further), it is have to buy some energy sources abroad. So, last year Ukraine imported $19 \%$ of oil and gas condensate, $27 \%$ of coal, $33 \%$ of gas, $77 \%$ of petroleum products and $100 \%$ of nuclear fuel. Ukraine ranks the 28th place in the world in energy consumption level. With significant reserves of resources in our state, $4.8 \%$ of energy is lost during its transportation and distribution. For comparing it is $1.6 \%$ for Poland, $3.3 \%$, for Romania and $1.2 \%$ for Lithuania ${ }^{1}$. Despite of this the share of energy production on the RES basis in Ukraine is significantly lesser than the world's one, from 1 to $6 \%$ according to various sources. It should be noted that with the enormous potential of renewable energy, with the availability of strong economic resources, the technologies associated with the use of renewable energy sources are very slowly diversifying in Ukraine.

\section{Literature Review}

In the analysis of the problems of renewable power industry it should be noted the works of domestic scientists O.M. Hudyma, D.V. Zerkalov, L.L. Tovazhnyansky, S.B. Tulub, A.I. Shevtsov A.K. Shidlovsky, T.E. Yasnyuk, as well as scientists of the neighboring countries, Eder L.V., Gromov I.A., Shkradiuk I.E., Yakovets Yu.V., Barabanov O.N., Bezrukykh P.P., Braginsky O.B. However, the institutional aspects of the formation of conditions for a partial shift to alternative energy supply have not been received in these works of expanded coverage. Of great interest are the work of foreign authors, whose sphere of interest is the RESgeneration and provision of enterprises with RES energy: Ozzie Zehner, Joseph E. Lawrence, Andris Piebalgs, Robert Rapier, Philippe Rekacewicz, Franko Fassio, Marco Frey. The works of these scientists cover issues related to the energy supply of the economy; issues of significance and expediency of alternative energy supply development; the idea of a partial transition to nonhydrocarbon energy is substantiated. One cannot ignore the fundamental works of foreign institutionalists and philosophers - $\mathrm{H}$. Gloystein, A. Zand who are investigating the problems of RES generation in the institutional aspect, which are fundamental in this research area. Despite a comprehensive analysis of the problem of alternative energy supply by Ukrainian and foreign scientists, the institutional issues of this problem have been poorly studied. In addition to measures of an institutional nature, the aspects of the formation of the RES-generation market, the demand of local industrial enterprises for the use of energy from renewable 
sources, and the lack of conceptual approaches to creating conditions for the development of RES-generation in Ukraine are insufficiently considered.

The lack of organizational and economic mechanisms for the demand-supply of RES-generation, the differing regulatory and legal framework, as well as the statistical base in the field of alternative energy supply, determined the necessity and relevance of the research presented in this paper.

\section{Institutional Analysis of Renewable Energy Sources}

For the constructive development of any branch of the national economy, a harmonious combination of its technological and institutional aspects is needed. The technological aspect involves the use of a synergy of modern innovative technologies in resources combining to create wealth. The institutional aspect is a complex of formal and informal institutions, with certain rules that actively influence the development and implementation of technologies. The basis of the institutional relationship between RES in Ukraine for the purpose of energy saving requires coordinated actions of economic entities in the economic space, with the distribution (regulation) of each of them for the stable functioning of the system.

Nowadays, the institutional structure of the industry as a set of existing institutions, on all hierarchical levels is only forming, which is a long process associated with changing the mentality of economic agents, overcoming the strong resistance, especially in the first phase of the life cycle of projects related to RES.

It is necessary to realize that this is a system that is largely selfregulated by a specific culture. Institutional updates of the energy sector in Ukraine cannot happen instantly, this requires a long period of time. Reforming any institutions is not instant process Even in the Veblen's definition of the institute as a "usual way of peoples thinking that tends to prolong their existence for an indefinitely long time" ${ }^{2}$, it is assumed that there are serious prerequisites for the renewal of these institutions. The energy sector transformation, whose priorities have been developing for decades, requires a change in mentality at all hierarchical levels of the national economy.

Only in the complementary formation of the political, economic and legal institutions of the renewable energy sector as part of the energy system, perhaps on the basis of synergy, provide accelerated economic development that will affect the integrity of the energy sector, which provides the livelihoods of all sectors, and ultimately on sustainable economic development of Ukraine.

In our country, the development of RES technologies is pick up team and in the long run is one of the strategic tasks of power industry. So, in the "Energy Strategy of Ukraine until 2035" main place in the concept of long-term development is assigned to it. It is planned that nuclear power will give $50 \%$ of the country's electricity by 2035 , renewable sources $-25 \%$, hydropower $-13 \%$, and other needs will be covered by thermal power plants ${ }^{3}$.

\subsection{Factors Hindering the Development of RES}

Factors hindering the development of RES.

1) Acceptable amount of hydrocarbons in the state. Europe is forced to look for new opportunities to meet the growing energy needs, but oil and gas reserves in Ukraine are huge, though undeveloped. In many states, there are ministries of renewable energy industry; developed countries have a legal basis for the implementation of "clean technologies", as well as mechanisms of economic motivation of enterprises (governmental aid, preferential taxation). There is the high share of RES in the fuel and energy balance of the EU countries and they have created the institutional conditions for its development ${ }^{4}$.

At the same time, developed countries with a sufficient amount of hydrocarbons develop RES-generation.
And if institutional conditions for the development of the renewable power industry sector in the USA and Canada have already been established, there has been a renewable power industry institute in Ukraine since 2003 that deals with scientific and applied problems related to RES, manages and coordinates the development of energy technologies using alternative energy resources. In turn, it should be noted that there is no motivational basis for the development of the "clean power industry" market. All efforts are aimed at energy saving, but in this direction there is a low positive dynamics, which further emphasizes the need to find alternatives. The development of the renewable energy industry through institutional transformations should be at the highest hierarchical level. The strategy of some enterprises should be integrated, that is, enterprises that produce alternative energy must solve the strategic problems of enterprises that use it. But demand and supply can be coordinated only through the state regulation of industry ${ }^{5}$.

2) Low power and instability of energy production of some RES types. Indeed, these options for RES-power plants today are not always competitive with traditional ones.

The level of both world and domestic technologies and equipment does not allow achieving the parameters of the $1 \mathrm{~kW} / \mathrm{h}$ cost, obtained at power plants using hydrocarbons. In developed countries, for increasing the efficiency of renewable energy, research is actively being conducted and new technological developments are being constantly implemented, in recent decades, so the gap between cost and efficiency in traditional and renewable energy is decreasing each year.

There are prospective developments in the field of renewable energy in our country, but as long as there are no comprehensive conditions for identifying the most competitive ones, their optimization and implementation, as well as for the adaptation of foreign technologies to Ukrainian realities.

3) Significant capital expenditures for equipment with limited resources of Ukrainian enterprises and a rather long period of capacities commissioning. High initial investments in infrastructure and technology are supplemented by the inability of the market in monetary terms to assess the positive externalities from the use of RES ${ }^{6}$, but, as you know, it is investment that serves as a basis for the process of reproduction of fixed assets and a resource asset of all innovations ${ }^{7}$.

In the conditions of the economic space of our country there are no serious motivations that can stimulate the business to implement the most promising RES projects both in the segment of suppliers of equipment for generation of energy on the basis of RES, and for the enterprises that acquire it.

In addition, there is no tool to mitigate the return on traditional and renewable energy, similar to that existing in developed countries ${ }^{8}$. The development of renewable energy requires a range of tax incentives, in conjunction with other stimulative measures. Despite the fact that research organizations carry out research, companies do not always have the opportunity to introduce new technologies and invest in projects related to RES, many works of the scientific laboratory do not find practical implementation, without mentioning the replication of RES-developments in the industrial production. Nowadays, there are no methods for a comprehensive assessment of the economic efficiency of projects related to the use of RES.

4) The orientation of industry and everyday life of our country to non-renewable energy sources. Lack of a mechanism for promoting the operation of enterprises that use energy resources as alternative sources of energy. In this regard, market conditions for sales of renewable energy suppliers has appeared. This also results in the technological backwardness of RES-developments.

5) Weak environmental institutions that form soft institutional conditions of state ecological regulation are characterized by incompleteness of norms and rules. There are no clear requirements for clearing the emissions of traditional power plants. The difficult situation of environmental institutions is determined not only by the weakness of the mechanisms of coercion to comply with norms and rules, but also the lack of strict sanctions for their violation. Today, there is a situation where sanctions may be at level 
that it is more profitable for business entities to violate norms and rules, than to keep them.

6) The legal field of the industry is only emerging. The first steps in the formation of regulatory documents have already been passed, but improvement of the legislative framework for renewable energy power industry is needed, there is no clear regulation of the mechanism for implementing laws, monitoring of its implementation on the site.

7) Absence of staff reserve in the branch. The faculties in higher educational establishments, which train specialists in the field of renewable energy power industry, were started just recently. In fact, staff problems in the Ukrainian economy are, in general, very acute, and this is one of the most serious problems for the new industries that need in people who have the relevant competencies, both in terms of special skills (level of specialists) and in the field of modern management technologies (level of management).

8) Bureaucratic and administrative obstacles. The biggest obstacle to the of renewable energy implementation in Ukraine is not even corruption, but personal interest or disinterest.

9) Weak scientific support of the branch is associated with low funding of both fundamental and applied researches, the result of which is the lack of resource support, scientific and experimental base, absence of demand for scientific developments in the industry, which makes it impossible to master new technologies. System for new knowledge in the field of renewable energy into production, integration with foreign innovations, implementation of the most promising ideas in the field of RES in the real sector of the economy are almost absent.

Thus, the institutional factors hindering the development of renewable energy power industry are reduced to the following (Table 1):

Table 1: Institutional factors hindering the development of RES in Ukraine

\begin{tabular}{|l|l|}
\hline \multicolumn{1}{|c|}{ Problems } & \multicolumn{1}{c|}{ Manifestation } \\
\hline $\begin{array}{l}\text { Institutional macroe- } \\
\text { conomic }\end{array}$ & $\begin{array}{l}\text { the lack of an integrated approach to solving } \\
\text { problems of the state as a whole }\end{array}$ \\
\hline Institutional branches & $\begin{array}{l}\text { Lack of balance between energy industry and its } \\
\text { sub-sectors }\end{array}$ \\
\hline $\begin{array}{l}\text { Acceptable amount of } \\
\text { hydrocarbons }\end{array}$ & in case of further development \\
\hline $\begin{array}{l}\text { High capital invest- } \\
\text { ments in RES projects }\end{array}$ & $\begin{array}{l}\text { insignificant cases of practical implementation } \\
\text { of RES projects }\end{array}$ \\
\hline $\begin{array}{l}\text { Absence of significant } \\
\text { motivations in the } \\
\text { economic environment } \\
\text { of our country }\end{array}$ & $\begin{array}{l}\text { Are missing: } \\
\text { - a tool for smoothing out the yield from hydro- } \\
\text { carbon power industry and RES } \\
\text { - tax and customs privileges } \\
\text { - methods of integrated assessment of economic } \\
\text { efficiency }\end{array}$ \\
\hline $\begin{array}{l}\text { market conditions and } \\
\text { competitive factors }\end{array}$ & $\begin{array}{l}\text { orientation of industry and households of our } \\
\text { country, mainly on hydrocarbon raw materials }\end{array}$ \\
\hline $\begin{array}{l}\text { the weakness of envi- } \\
\text { ronmental institutions }\end{array}$ & $\begin{array}{l}\text { It is easier for enterprises to pay fines than to } \\
\text { use environmentally friendly energy }\end{array}$ \\
\hline $\begin{array}{l}\text { the legal field of the } \\
\text { branch is just emerging }\end{array}$ & $\begin{array}{l}\text { - the legislative framework for RES need to be } \\
\text { improved } \\
\text { - regulation of enforcement mechanisms is } \\
\text { needed, especially on the sites }\end{array}$ \\
\hline staffing & $\begin{array}{l}\text { lack of professional specialists and managers, } \\
\text { low level of interaction between higher educa- } \\
\text { tional institutions and industry enterprises }\end{array}$ \\
\hline In order to eliminate the factors, significant institutional changes
\end{tabular}

In order to eliminate these factors, significant institutional changes that can not be carried out outside targeted state policies are needed, including financial support for the industry, the elimination of regulatory barriers, and the formation of demand for equipment by the strengthening of environmental norms and other tools for stimulating the development of renewable energy power industry and coordination of energy market participants.

It should be noted, that the state policy in the field of renewable energy demonstrates insufficient thoughtfulness of the target directions of planned industrial innovation changes in the issue of mechanisms designed to achieve them. So far there is no system in the field of state regulation of renewable energy. Meanwhile, for the rigid institutionalization of the field of renewable technologies, a mechanism that systematically regulates the processes of their development is needed. The basic element of state incentives for the development of renewable energy is the creation of a favourable investment climate characterized by rigid legislative norms, a sound taxation policy, a transparent institutional environment.

\subsection{Key Segments That Affect the Development of RES}

Summarizing the institutional conditions that affect the development of renewable energy power industry, it is necessary to note three key segments:

1. Those that are connected with the legal basics (standards, regulations, norms of technological character, responsibility for environmental violations, etc.);

2. Those of economic nature (taxation, subsidization and other methods of economic motivation of economic entities);

3 . Those that forming an organizational mechanism (popularization of renewable power industry, construction of organizational and economic units within each economic agent of this market at all hierarchical levels)

By gradually affecting the factors restraining the development of non-traditional technologies, transforming the energy system, expanding the limits of renewable energy use in the most sought after geographic and technological zones, the government is able to create institutional conditions for the development of renewable energy power industry sub-sectors, within the framework appropriate for the energy power industry sector as a whole.

Certain institutional transformations are needed for qualitative development of renewable energy power industry in Ukraine, Institutional changes are needed in energy supply, and now the state needs to systematize and harmonize the RES-policy.

Certain funds from the budget (about 2-4 billion UAH) are invested in traditional electric energy power industry annually ${ }^{9,10}$. Another interesting fact: in 2015, every eighth dollar of world investment in energy was aimed at increasing the power industry efficiency. At the same time, in Ukraine, expenditures on research and development in the fuel and energy complex decreased in $2008^{1}$. If a part of the money was invested by the state in the RES, then the industry would be competitive gradually. This need is further rises under the conditions of destroyed machine building, instrument making and other basic industries, without which the alternative power industry cannot be developed. However, global trends in the development of the economy and the energy sector nevertheless have an impact on the socio-economic processes that are taking place in our country.

\subsection{Positive Trends in the Dynamics of Renewable En- ergy Development in Ukraine}

It is worth pointing out the fact that today there are already changes in the energy policy in Ukraine with scientists and specialists involved in this problem. For example, creation of the Institute of Renewable Energy of the National Academy of Sciences of Ukraine already mentioned above. This structure is the centre of competence in the field of RES technologies, from their development and feasibility studies to implementation (coordination of construction and operation of RES objects). A state funded renewable energy support program has appeared.

Despite the positive moments of the institutionalization of the industry, measures of state support for this process are clearly inadequate.

Based on the analysis of legislation in the field of renewable energy, it can be noted that the basic laws governing the development of the industry are formulated, but the purposes remain on paper (Fig 1). 


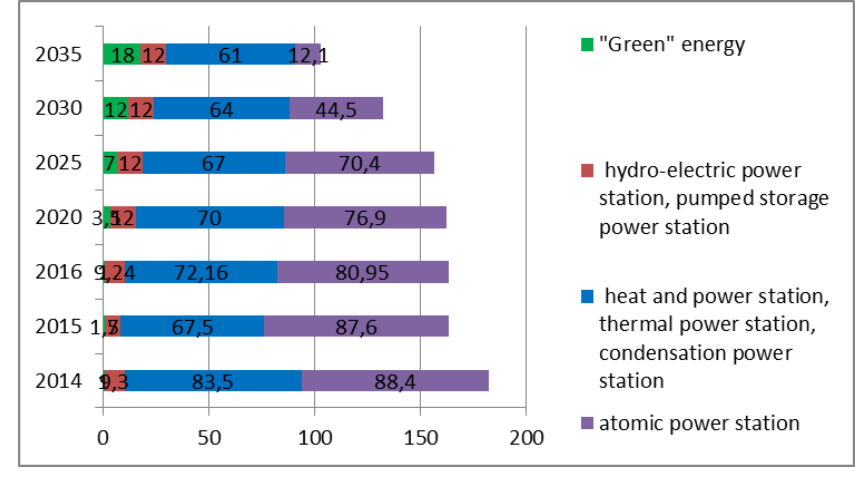

Fig. 1: Forecast of power industry facilities of Ukraine up to 2035, billion $\mathrm{kWh}$

Need to say about positive trends in the dynamics of the industry. So, in 2015, brought really positive legislative changes that allowed a compromise for all market stakeholders. The tariff was brought to the average European level, and the local equipment norm was replaced by the incentive to use such equipment.

Besides, additional support was provided to bioenergy, for which the tariff was increased by $10 \%$; the limit capacity of installations of private households is raised to $30 \mathrm{~kW}$; the "green" tariff was extended to wind power ${ }^{11}$.

These changes have pushed the market out of a deadlock, a new inflow of foreign investment has appeared, and, accordingly, a new stage of development has begun. Legislative support, binding tariffs to the Euro, government guarantees to investors by 2030 all this prompts to build new large-scale projects. Moreover, while the world is developing a new trend - the "green" energy auctions, the "green" tariff provides market growth. According to the State Department of Energy Efficiency of Ukraine, the share of renewable energy sources has increased from $3.9 \%$ to $5.8 \%$ over the past three years, from $7.4 \%$ to $7.8 \%$ in the electric power industry. These are relatively significant growth figures in the macroscale for such a short term. The highest growth rates are for solar power plants. If in 2016 their total capacity was $99.2 \mathrm{MW}$, then in 2017 it was more than $170 \mathrm{MW}$.

Wind power generation in 2016 grew up to 437.7 MW. As a result, in 2017 Ukrainian wind power stations generated 695,947 million kWh of electricity (see Fig. 1).

At the same time, Ukraine does not yet have a system that combines mechanisms for synchronizing the interest of all business entities in the implementation of innovations (not only in the field of RES), therefore it is not surprising that the level of innovation activity of Ukrainian enterprises in the development of new energy technologies is significantly lees the in the leading countries.

\section{Results and Discuss}

Therefore, you the following steps need to be performed:

1 ) it is necessary to form a system stimulating the development of innovative technologies in general and in the field of RES in particular. In Ukraine, the complexity of creating a coherent system aimed at motivating business to innovation is due to the incompleteness of institutional reforms and the market transformation of the economy ${ }^{12}$. Serious problems are observed in the field of energy, which result in man-induced disasters ${ }^{13,14}$. In the electric power industry, the number of repair personnel has severely decreased; according to experts, qualified personnel for the qualitative implementation of the plan of scheduled maintenance are at the disposal of only $10 \%$ of electricity companies.

System and structural diversification of the economy based on the interaction of business and science, the transfer of innovative technologies, the motivation of economic agents for the use of energy-efficient energy technologies as well as renewable power industry technologies is required. By combining the efforts of representatives of the legislative and executive power at both local and regional levels, scientists working in the field of fundamental and applied science, the business community is able to break through the innovation sector of the country as a whole and in the field of RES technologies. Directly in relation to RES, it is important to formulate a clear scheme of the potential location of RES objects in the country, identifying the needs for thermal and electric energy and the resource component, and selecting the optimal option for complementing the use of these or other energy supply options for different zones.

2) To activate the positive dynamics of renewable energy development (as well as any other sector of the economy) it was necessary to create laws regulating this process, it is necessary to create mechanisms that penetrate all the hierarchical steps of the national economy, which allow implementing normative acts, to breathe life into them. State system support should be related to the planned rate of development of the country as a whole, with the provision of targets indicators of the RES share in the power industry structure of each region of the country, depending on the specific resources and needs of the region and regulated by statistical reporting. Then it is necessary to start the process of the legislative and regulatory framework updating in the field of RES, as well as to forming the structure of management of the renewable energy market in the country. Measures and mechanisms should be under the control of the structures responsible for this - this responsibility can be put, for example, at the Ukrainian Energy Agency. Spontaneity in the creation and implementation of new regulatory documents is inappropriate, only a clear coordination of the formation and implementation of regulatory acts should be kept.

3) The most important features of institutional conditions is their rigidity, so it is very important to formulate and include in the system indicators of efficiency, new indicators of economic development, associated with the environmentalisation of production. This also applies to $\mathrm{CO} 2$ emissions limits similar to the Cap \& Trade scheme (emission quotas trading ), which should moreover relate to newly introduced capacities that trigger both the introduction of innovative technologies in the hydrocarbon power industry and the development of innovations in the alternative fuels consumption. At the same time, economic agents who violate environmental standards must be subject to administrative penalties, these incidents must also be controlled.

4) The public consciousness, consciousness of the place and position of Ukraine in the field of renewable energy both at the national and international levels is of great importance. Therefore, it is necessary to conduct PR for new energy technologies at the state level, to create an accessible information environment, to change the mentality of society in the context of understanding the importance of renewable energy for the future of humankind. In addition to philosophical and environmental substantiation, it is necessary to prove economically the value of renewable technologies, to generate market demand for renewable energy. It is important to note the need to compare the cost of traditional and renewable energy. In principle, there are only two key disadvantages in RES: the expensive "entrance" to the alternative energy business and the instability of energy resources, which are becoming more and smoother each year, as the technologies of RES generation are being improved and cheaper. However, even if we consider the issue of value, it is necessary to address not only the aspect of the price of RES energy for the consumer. After all, in addition to the consumer price, there are public costs that are not visible when considering only the economic aspect. If we consider the costs of hydrocarbon energy wider, taking into account all aspects of the structural and functional model of society, renewable electricity will be quite competitive (Fig 2).

In addition, considering the costs of traditional power industry, part of the costs are simply not taken into account, for example, the calculation does not go (as they still do not have in Ukraine), the cost of storage and capture of carbon, fines for carbon dioxide emissions and other greenhouse gases. In general, the cost of hydrocarbon production increases objectively with each passing year, consider the depletion of powerful deposits and the inaccessibility of available ones. 
5) It is necessary to consider the financial aspect of the issue, because without financial motivation from the state it is impossible to carry out institutional transformations at the micro level. It is necessary to envisage state investments in pilot RES projects, on fundamental and applied research, and on R\&D of the most promising technologies.

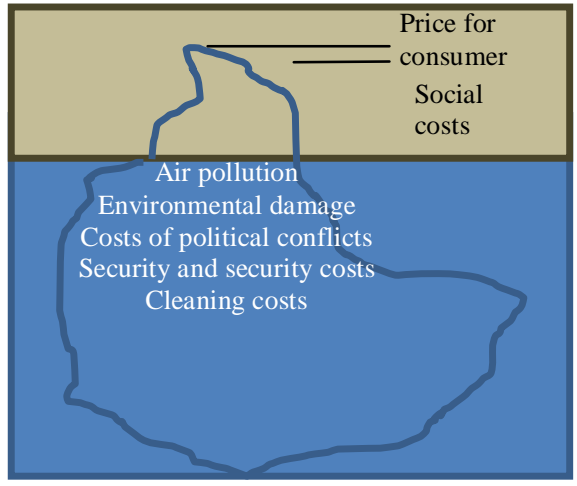

Fig. 2: Public expenditure on fossil energy sources ${ }^{15}$

While replicating effective technologies, financial support of the state should be, first of all, in the form of subsidizing bank interest rates on loans for the purchase of equipment for RES technologies, the implementation of preferential taxation (or complete withdrawal of taxes) of enterprises for the entire payback period of RES projects, full compensation of value technological connection of RES to the electrical grid.

In some cases, when using, for example, bioethanol as a fuel, you the excise tax need to be withdrawn. In the issue of stimulating RES directly in the agricultural sector subsidizing the purchase of organic fertilizers for agricultural producers in order to partially replace the mineral ones can be promoted. It should be noted that, in addition to public funding, alternative venture capital may be used. In terms of motivating the acquisition of a final productelectricity, it is important to smooth the difference in the cost between traditional and alternative energy or by increasing the cost of purchasing energy with the compensation of the difference between the companies that buy it; or to pay the difference directly to the energy producer, setting the amount of compensation and reviewing it at a certain period of time (for example, once every 6 months).

6) Of great importance, of course, is the study of the practices of world leaders in the field of renewable energy power industry. This applies to state regulation, organizational structures, technology, industrial cooperation. The introduction of the most effective and expedient technologies already implemented abroad will allow our country to develop more dynamically in the issues of alternative energy supply.

7) In addition to foreign innovation, it is very important to study, optimize and develop the own technological field of alternative energy supply and form some methodological basis for the practical application of various, most expedient technologies of RES in different conditions. There are many talented developers, scientists in Ukraine who research and develop alternative technologies and those with sufficient experience and knowledge in this field Existing technologies and equipment can be imported, some of the elements can be done in Ukraine.

In addition, it is only necessary motivate to create the most promising developments and equipment, to provide them with the necessary resources and efficient Ukrainian technologies. The RES and domestic equipment will be able to provide energy with the best possible location, considering climatic and other conditions of the necessary geographical segment. It is only necessary to finance scientific development at all stages of the energy supply of the national economy, even in the most prosperous energy subsectors. The overall energy saving potential of the Ukrainian economy is 27 million tons of oil equivalent, equivalent to 30 billion cubic meters of gas or 10 billion US dollars in prices of $2014{ }^{16}$. According to the NOSEP (New Socio-Economic Policy) Analytical Centre, which, together with UNDP (UNDP in
Ukraine) and the Global Environment Facility, recently introduced a new Energy Efficiency Monitor, by the end of 2014, the energy efficiency of the Ukrainian economy did not exceed $60 \%$ of the average for EU countries. An adjusted energy structure in Ukraine was 1.7 times higher than in the $\mathrm{EU}^{16}$.

8) It is impossible to develop the industry without highly skilled staff. To do this, it is necessary to prepare young specialists in the field of alternative energy, as well as improve the skills of experienced staff and managers. It is necessary to introduce "renewable" or "alternative" energy power industry in higher education programs, to increase the research competence of alternative energy departments of higher educational institutions, to open departments for the issue of technical specialists in the field of RES, to increase the number of retraining and advanced training courses for managers. It is important to establish the interaction between business, education and science, to create some basis for the integration of new ideas and experiences and the implementation of the best of them. Also, the formation of a documentation system for the design and use of RES objects is important both in terms of methods, and in matters of regulatory and technical regulations for training future industry professionals. In addition, it is important to increase the prestige of specialists, perhaps by increasing scholarships, assistance in employment, etc.

9) Regulatory framework requires improvement, development of additional regulations and standards, especially:

in the issue of implementing "excess" electricity to network organizations;

in the methods of calculation and adjustment of the "green tariff"; in the question of the obligation of economic agents to acquire a certain amount of alternative energy.

10) Serious work is needed to remove administrative barriers, to fix the interaction of different state structures for the dynamic design of a new business in the field of alternative energy, to optimize the timing of reconciliation of the construction of REobjects, their commissioning, exploitation.

11) For the further formation of institutional reforms in the sector, structures that consolidate the efforts of like-minded people, who promote the development of alternative energy, are needed. In particular, antitrust regulation is needed, which contributes to increasing transparency in the activities of big players in the economic space and regulating pricing. Energy prices in Ukraine are among the highest in Europe. In Italy, "the most problematic in energy supply to the EU country", for enterprises the cost of $\mathrm{kW} / \mathrm{h}$ of electricity is 11 - 11.5 Euro cents, while in Ukraine - 15 Euro cents. The policy of pegging domestic prices for fuel and energy to the world's level must be accompanied by a steady devaluation of the real exchange rate, compensating producers for the loss from increased energy prices ${ }^{17}$, but the pricing policy in such a significant country for the country should be fully controlled by the state. There are already organizations, such as the Ukrainian Association for Renewable Energy, the Ukrainian Energy and Energy Association, the Ukrainian Wind Energy Association, the Ukrainian Network of Energy Innovations "Greencubator", the Renewable Energy Institute of the National Academy of Sciences of Ukraine. It is important to develop these partnerships, to establish a close business-to-state, scientists-to-practices, and financeto-real projects relationship. It is these structures that will help deeper to explore prospective investors with successful precedents for the use of RES technologies, transfer business to the best practical results of scientists.

In general, institutional transformations can be reduced to the following (Table. 2). 
Table 2: Problems of alternative energy industry and ways of their solution

\begin{tabular}{|c|c|}
\hline Problems & Decision \\
\hline $\begin{array}{l}\text { Institutional } \\
\text { macroeconomic }\end{array}$ & $\begin{array}{l}\text { integrated approach to solving problems of the na- } \\
\text { tional economy as a whole, designation of the target } \\
\text { function, regulation of functions and processes of } \\
\text { subsystems }\end{array}$ \\
\hline $\begin{array}{l}\text { Institutional } \\
\text { branches }\end{array}$ & $\begin{array}{l}\text { definition of optimal fuel and energy balance for } \\
\text { each region; } \\
\text { mechanisms of achievement of target benchmarks in } \\
\text { different branches of power engineering; } \\
\text { organization of control over the implementation of } \\
\text { planned indicators; } \\
\text { providing large enterprises with long-term interest- } \\
\text { free loans for the construction of RES-objects with } \\
\text { the possibility of using "saved" at the cost of kWh of } \\
\text { funds for the development of the region }\end{array}$ \\
\hline $\begin{array}{l}\text { Lobbing of hy- } \\
\text { drocarbon energy }\end{array}$ & $\begin{array}{l}\text { creation of organizations with real powers to promote } \\
\text { alternative power industry projects (financial, legal, } \\
\text { administrative), implementing PR alternative power } \\
\text { industry in all spheres of public life and lobbying } \\
\text { industry in government }\end{array}$ \\
\hline $\begin{array}{l}\text { High capital } \\
\text { investments in } \\
\text { RES projects }\end{array}$ & $\begin{array}{l}\text { 1. rational calculation of capital expenditures in } \\
\text { traditional and alternative energy } \\
\text { 2. determination of zones for optimal placement of } \\
\text { RES objects and financing of pilot projects from the } \\
\text { local budget } \\
\text { 3. allocation of preferential long-term business loans } \\
\text { for the implementation of RES projects }\end{array}$ \\
\hline $\begin{array}{l}\text { Absence of seri- } \\
\text { ous motivations } \\
\text { in the conditions } \\
\text { of the economic } \\
\text { space of Ukraine }\end{array}$ & $\begin{array}{l}\text { it is necessary to form: } \\
\text { a tool for smoothing profits from traditional and } \\
\text { RES-power industry; } \\
\text { tax and customs privileges for enterprises with RES- } \\
\text { objects; } \\
\text { methods of integrated assessment of the economic } \\
\text { efficiency of RES projects }\end{array}$ \\
\hline $\begin{array}{l}\text { market conditions } \\
\text { and market fac- } \\
\text { tors }\end{array}$ & $\begin{array}{l}\text { partial orientation (within the framework of indica- } \\
\text { tive plan) of industry, transport and everyday life on } \\
\text { non-renewable energy sources }\end{array}$ \\
\hline $\begin{array}{l}\text { The weakness of } \\
\text { the ecological } \\
\text { institutes of } \\
\text { Ukraine }\end{array}$ & $\begin{array}{l}\text { strengthening of penalties for non-compliance with } \\
\text { norms on harmful emissions and waste utilization, } \\
\text { strengthening control over their implementation }\end{array}$ \\
\hline $\begin{array}{l}\text { The legal field of } \\
\text { the branch is still } \\
\text { emerging }\end{array}$ & $\begin{array}{l}\text { improvement of the legislative framework for renew- } \\
\text { able power industry: the obligation of energy suppli- } \\
\text { ers to connect RES-objects to the network, in accord- } \\
\text { ance with the scheme of their placement in the region } \\
\text { and to accept "excess" electricity in the network on } \\
\text { the basis of the contract; } \\
\text { clear regulation of the enforcement mechanism, } \\
\text { especially on the ground }\end{array}$ \\
\hline staffing & $\begin{array}{l}\text { formation of a system of professional specialists and } \\
\text { managers training in the field of RES, creation of a } \\
\text { system of interaction between universities and indus- } \\
\text { try }\end{array}$ \\
\hline $\begin{array}{l}\text { bureaucratic and } \\
\text { administrative } \\
\text { obstacles }\end{array}$ & $\begin{array}{l}\text { strict control over the implementation of strategic } \\
\text { regulations on the ground, punishment in case of } \\
\text { non-enforcement of laws, obstacles to their imple- } \\
\text { mentation }\end{array}$ \\
\hline
\end{tabular}

\section{Conclusion}

To realize the target indicators of Ukraine's energy strategy for RES, it is necessary:

1. Create an authority that has the power to lobby for the interests of producers and consumers of RES energy in the government. Its function should also be the communication between the scientists developing the RES technologies, business, ready to implement innovations and the state supporting the development of RESenergy, different structures that form the legal acts related to RESgeneration.

2. To identify the geographical location of the objects most suitable for the implementation of RES-generation technologies, to create a "power map" of Ukraine with the definition of capacity, timing, volumes and financing mechanisms for the construction of RES-generators.

3. Financing grants for the development of domestic RES technologies for certain climatic zones.

4. To allocate the budget for the introduction of innovative technologies at the expense of the state - for the construction of several different RES-generators in order to identify the most effective technologies and their replication.

5. To exempt from income tax and VAT for the entire payback period of thr RES projects for the enterprise consuming RES energy. In the absence of domestic equipment, exempt RES-generators from customs duties and import VAT when importing.

6. To subsidize RES-equipment produced in Ukraine or foreign ones in the absence of domestic analogues

7. Add an "environmental tax", similar to taxes existing in Belarus, that is, a tax on emissions in the amount of $2000 \mathrm{UAH} / \mathrm{ton}$, a waste tax of $15 \mathrm{UAH} /$ ton $^{18}$. This measure will increase budget revenues and create incentives for enterprises to dispose of waste by converting them into energy.

To sum up, for the development of alternative energy it is necessary to develop institutional transformations - to improve the regulatory framework, to implement mechanisms for its implementation, to increase economic incentives for implementation of RESgeneration projects. These institutional transformations contribute to the very dynamic development of the industry, help solve many inter-sectoral problems, and stimulate the development of the country's economy as a whole.

\section{Acknowledgement}

I would like to express my gratitude to Shkrabak Irina Vladimirovna Associate Professor from the Donbass State Engineering Academy (Kramatorsk) for sharing her pearls of wisdom with me during the course of this research.

\section{References}

[1] «Chto nuzhno znat' kazhdomu ob jenergetike Ukrainy?» Elektrovesti, № 1, 2017, available online: http://elektrovesti.net/56848 chtonuzhno-znat-kazhdomu-ob-energetike-ukrainy-top-5-faktov, last visit: 28.05 .2018

[2] Veblen T. «Teorija prazdnogo klassa». - M: Progress, 1984. s. 202.

[3] «Pravitel'stvo utverdilo novuju jenergeticheskuju strategiju Ukrainy do 2035 goda», available online: http://gordonua.com/news/money/pravitelstvo-utverdilo-novuyuenergeticheskuyu-strategiyu-ukrainy-do-2035-goda-203154.html, last visit: 01.06.2018

[4] Sergej Semenov. «Biznesu prigotovili deshevuju jelektrojenergiju», EquipNet.ru izdanie o tehnologijah i biznese, 03.08.2011, available online: www.equipnet.ru, last visit: 21.05.2018

[5] Bekker N.A. Avtoreferat dissertacii na soiskanie uchenoj stepeni kandidata jekonomicheskih nauk «Ocenka jekonomicheskoj jeffektivnosti ispol'zovanija vozobnovljaemyh istochnikov jenergii (na primere vetrojenergetiki Germanii)», Moskva - 2007 g. S. 29.

[6] B.A. Erznkjan, A.A. Nikonova. «Formirovanie konkurentosposobnoj strategii predprijatija: problemy i paradoksy» Zhurnal jekonomicheskoj teorii, №4, (2011). Mikrojekonomika., s.3.

[7] Tokarev A.N. «Vlijanie institucional'nyh uslovij na realizaciju social'no-jekonomicheskih vygod osvoenija neftegazovyh resursov» pod red. Krjukova V.A. - Novosibirsk: IJeOPP SO RAN, 2007. 240 s. - str. 23

[8] Pavlenko A.M. «Grjaznye» moshhnosti. Problemy jekologii v jelektrojenergetike». NG-jenergija Jekologija, 17 janvarja 2012 g., s. 11 .

[9] «PLAN ROZVYTKU ROZPODIL"NYH ELEKTRYChNYH MEREZh NA 2016-2020 ROKY», 26.11.2015, available online: http://mpe.kmu.gov.ua/minugol/control/publish/article?art_id=2450 64086 last visit: 29.05 .2018

[10] «Zvit pro rezul'taty dijal'nosti NKREKP za 2016 r.», 26.04.2017, available online: http://www.nerc.gov.ua/?id=24476 last visit: 03.06.2018

[11] Timur Chmeruk «Trendy al'ternativnoj jenergetiki Ukrainy: ot upadka do progressa», Zn,ua, 5.02.2018, available online: 
https://zn.ua/energy_market/trendy-alternativnoy-energetiki-

ukrainy-ot-upadka-do-progressa-274116_html last visit:23.05.2018

[12] Nikonova A.A. «Mozhno li nam kopirovat' zapadnye obrazcy jenergojeffektivnosti?» Jenergeticheskaja politika, .№ 1 (2014) str.8.

[13] Zahnd A. «The Role of Renewable Energy Technology in Holistic Community Development». Doctoral Thesis accepted by Murdoch University, Perth, Western Australia. - Springer Cham Heidelberg New York Dordrecht London, 2013, 611 p.

[14] H.Gloystein, A. Sheldrick Analysts: «Solar energy is on the verge of a «global boom» April 25, 2015. News about alternative energy, available online: http://www.zzenergysolutions.com/alternativeenergy-news.html last visit: 12.05.2018

[15] «Vozobnovljaemye vidy jenergii. Tehnologii na osnove vozobnovljaemyh vidov jenergii - uspehi Germanii», German Energy Agency, available online: http://news.sfukras.ru/files/vystavka_RU.pdf last visit: 18.05.2018

[16] Irina Akimova. «Jenergojeffektivnost' ukrainskoj jekonomiki sostavljaet tol'ko 60\% ot stran ES», Segodnja, 3.07.2016, available online:

https://www.segodnya.ua/opinion/akimovacolumn/energoeffektivn ost-ukrainskoy-ekonomiki-sostavlyaet-tolko-60-ot-stran-es729916.html last visit: 8.05.2018

[17] Popov V.V. «Strategii jekonomicheskogo razvitija» Nacional'nyj issledovatel'skij universitet "Vysshaja shkola jekonomiki», - M.: Izd. dom Vysshej shkoly jekonomiki, 2011. - s. 220

[18] Tehnicheskij kodeks ustanovivshejsja praktiki TKP 17.02-05 - 2011 (02120) Ohrana okruzhajushhej sredy i prirodopol'zovanija. Ministerstvo prirody. Minsk. 2011. 30 s.139 